\title{
ANALISIS WEBSITE PERPUSTAKAAN UNIVERSITAS ISLAM NEGERI MENGGUNAKAN METODE BENCHMARKING DAN GOAL ORIENTED REQUIRMENTS ENGINEERING (GORE) MODEL (STUDI KASUS: UIN JAKARTA, UIN YOGYAKARTA DAN UIN MALANG)
}

\author{
Qurrotul Aini $^{1}$, Imam Marzuki Shofi ${ }^{2}$, Fenty Eka Muzayyana Agustin ${ }^{3}$ \\ ${ }^{1,2,3}$ Teknik Informatika, Fakultas Sains dan Teknologi \\ Universitas Islam Negeri Syarif Hidayatullah Jakarta \\ qurrotulaini@mhs.uinjkt.ac.id ${ }^{1}$,imam@uinjkt.ac.id ${ }^{2}$, fentyema@gmail.com³
}

\begin{abstract}
The library is an important source of knowledge for all academicians. One of them is the university library, the purpose of the university library is funding support from the university in providing education by providing sources of scientific information in the library. However, information sources (consisting of web sites) available in the library are currently incomplete. For this reason, a usability evaluation and design analysis of the website is required so that the library website development goals can be achieved. Requirement Analysis of this library website used the Bechmarking and Goal Oriented Requirement Engineering (GORE) methods of three library websites namely the UIN Syarif Hidayatullah Jakarta library website, Sunan Kalijaga Yogyakarta UIN and UIN Maulana Malik Ibrahim. Benchmarking method is used to get the basic requirements by questionnaire. The GORE method is obtained based on the formulation of system objectives. To get the system requirements with the GORE method consists of actor models, Strategic Dependency diagrams, and Strategic Rationale diagrams. The results of this website analysis are the achievement of all requirements obtained and the new system of the library website of the Syarif Hidayatullah State Islamic University Jakarta.
\end{abstract}

Keywords: Library Website, Bechmarking, Goal Oriented Requirement Engineering (GORE), i* Framework

\begin{abstract}
ABSTRAK
Perpustakaan merupakan sumber ilmu pengetahuan yang penting bagi seluruh sivitas akademika. Salah satunya adalah perpustakaan perguruan tinggi, tujuan perpustakaan perguruan tinggi adalah mendukung kinerja dari perguruan tinggi dalam menyelenggarakan pendidikan dengan menyediakan sumbersumber informasi ilmiah di perpustakaan. Akan tetapi sumber-sumber informasi (berupa website) yang ada di perpustakaan saat ini masih belum dikatakan sempurna. Untuk itu, diperlukan evaluasi usability dan analisis desain dari website sehingga tujuan penggunaan teknologi bisa tercapai. Analisis kebutuhan website perpustakaan ini menggunakan metode Bechmarking dan Goal Oriented Requirement Engineering (GORE) terhadap tiga website perpustakaan yaitu website perpustakaan UIN Syarif Hidayatullah Jakarta, UIN Sunan Kalijaga Yogyakarta dan UIN Maulana Malik Ibrahim. Metode Benchmarking digunakan untuk mendapatkan basic requirement dengan cara kuesioner. Dan metode GORE yang didapat berdasarkan rumusan tujuan sistem. Untuk mendapatkan kebutuhan metode GORE yaitu dengan menyusun model aktor, diagram Strategic Dependency, dan diagram Strategic Rationale. Hasil dari analisis website ini adalah dengan tercapainya semua requirement yang didapat dan sistem baru website perpustaaan Universitas Islam Negeri Syarif hidayatullah Jakarta.
\end{abstract}

Kata Kunci: Website Perpustakaan, Bechmarking, Goal Oriented Requirement Engineering (GORE), i* Framework

DOI: http://dx.doi.org/10.15408/ jti.v12i2.13245 


\section{PENDAHULUAN}

Kemajuan teknologi informasi saat ini telah memberikan banyak peluang sekaligus tantangan untuk memperoleh informasi sesuai kebutuhan manusia, khususnya kebutuhan ilmu pengetahuan. Untuk mendapatkan ilmu pengetahuan bisa didapatkan di berbagai lembaga pendidikan. Salah satunya yang harus ada pada lembaga pendidikan tinggi atau perguruan tinggi adalah perpustakaan.

Perpustakaan merupakan sumber ilmu pengetahuan yang penting bagi seluruh sivitas akademika, karenanya perpustakaan harus menjadi pusat belajar yang menyediakan berbagai sumber informasi, baik yang mencakup dengan pendidikan dan pengajaran, penelitian, maupun pengabdian masyarakat.

Dengan adanya perpustakaan, diharapkan mampu mencetak mahasiswa untuk senantiasa terbiasa dengan aktifitas membaca, mengembangan ilmu pengetahuan dan budaya, menggali informasi dari sebuah buku yang ada, sehingga menghasilkan ilmu yang bermutu.

Berbagai macam teknologi internet bisa digunakan, salah satunya adalah World Wide Web (WWW) yang mampu menyediakan informasi dalam bentuk teks, gambar, suara, maupun gambar bergerak (Animasi). Namun informasi yang disajikan dalam website perpustakaan universitas islam negeri saat ini masih belum dikatakan sempurna. Hal ini diperkuat oleh adanya hasil kuesioner yang sudah disebarkan terhadap tiga universitas yang telah ditentukan.

Salah satu metode dalam Requirement Engineering yang saat ini berkembang sangat pesat adalah Goal Oriented Requirement Engineering (GORE) merupakan rekayasa kebutuhan yang merasionalisasikan berbagai kebutuhan yang diperlukan oleh sebuah sistem yang akan dibuat berdasarkan dari tujuantujuan yang dirumuskan, sehingga diharapkan kebutuhan yang didapatkan bukan hanya berdasarkan data dan proses bisnis manual. Pada GORE akan ditentukan goal dari sistem informasi ini setelah itu akan di implementasikan atau dimodelkan dalam bentuk interface website [1].

Terdapat 17 metode metode/teknik yang telah dikembangkan oleh GORE, salah satunya adalah i* framework. Metode i* berfokus pada pemodelan aktor dan analisa kepentingan stakeholder dari sistem yang dibuat [2].
Framework ini memiliki dua komponen utama, yaitu: Strategic Dependency (SD) model dan Strategic Rationale (SR) model. Strategic dependency (SD) mendeskripsikan hubungan ketergantungan antar aktor. Model ini memungkinkan untuk analisis dependensi langsung atau tidak langsung dari masingmasing aktor dan eksplorasi peluang dan kerentanan aktor [3]. Dependensi mendeskripsikan hubungan intensional antara dua aktor dengan dependum. Terdapat 4 tipe dependum yaitu, goals, tasks, resources, dan softgoals.

Analisis yang digunakan untuk mendapatkan basic requirement dari website perpustakaan pembanding menggunakan metode Bencmarking terhadap tiga website perpustakaan UIN. Perbandingan tiga website Universitas Islam Negeri yang berada di Pulau Jawa diantaranya UIN Syarif Hidayatullah Jakarta, UIN Sunan Kalijaga, UIN Maulana Malik Ibrahim. Adapun data dari BANPT 2017 ketiga UIN tersebut merupakan UIN yang terakreditasi A.

Gregory H. Watson mendefinisikan Benchmarking sebagai pencarian secara berkesinambungan dan penerapan secara nyata dengan praktik-praktik yang lebih baik dan mengarah pada kinerja kompetitif yang unggul. Menurut kamus yang ditulis Drs. Peter Salim, Benchmarking dipadankan dengan patok duga. Maksutnya, sebuah lembaga mematok lembaga lain yang mereka anggap sebagai pesaing terberat, lalu jika dibandingkan, menduga perusahaan mereka berada pada posisi setinggi apa [2]

Alasan memakai Benchmarking adalah untuk meningkatkan kualitas dengan melihat atau menbandingkan kinerja terhadap kegiatan atau aktifitas yang serupa. Basic requirement yang dilihat dari membandingkan tiga website serupa yaitu dengan melihat usability apa saja yang terdapat di dalamnya.

Dipilihnya Goal Oriented Requirement Engineering yang digunakan untuk memecahkan masalah pada penelitian ini, karena dengan menggunakan Goal Oriented Requirement Enginnering dapat mendapatkan kebutuhan yang sesuai dengan kebutuhan stakeholder, dan melengkapi kekurangan pada pendekatan tradisional yang lebih menekankan pada pemodelan low-levelnya [2]. Selain itu diperlukan adanya desain perangkat lunak untuk mendapatkan website yang sesuai dengan kebutuhan yang telah didefinisikan. 


\section{METODOLOGI}

Penelitian ini menggunakan metode Bechmarking dan Goal Oriented Requirement Engineering (GORE) terhadap tiga website perpustakaan yaitu website perpustakaan UIN Syarif Hidayatullah Jakarta, UIN Sunan Kalijaga Yogyakarta dan UIN Maulana Malik Ibrahim. Kedua metode akan digunakan untuk memodelkan kebutuhan dan kemudian hasilnya akan dibahas dari sisi kelebihan dan kekurangannya sehingga pada akhirnya dapat menggambarkan hal-hal yang bisa dikerjakan pada penelitian selanjutnya.

\subsection{Goal Oriented Requirement Engineering (GORE)}

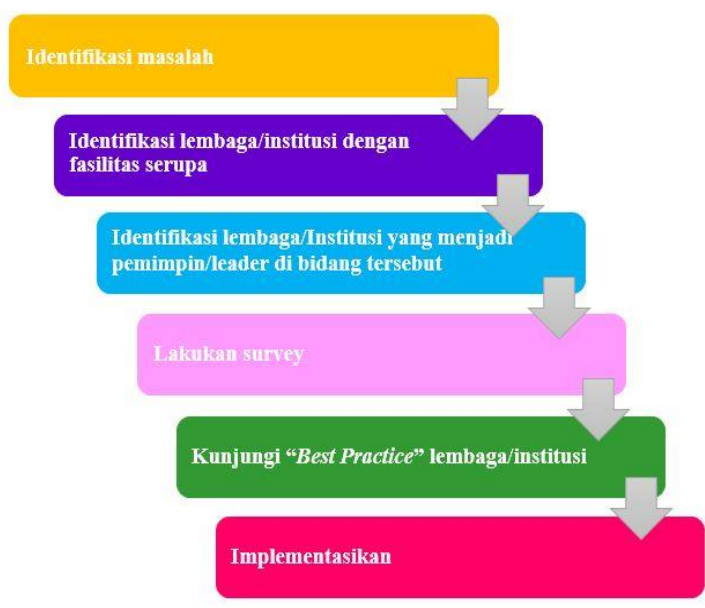

Gambar 1. Tahap GORE

Goal Oriented Requirement Engineering merupakan sebuah metode rekayasa kebutuhan yang mendasarkan setiap aktivitasnya pada tujuan (goals), dari proses elisitasi, analisis dan pemurnian, serta validasinya [1].

Pendekatan analisis secara tradisional tidak memiliki penalaran analisis sistem yang lebih terkait system-to-be dan lingkungannya. Hal tersebut dapat mempengaruhi terhadap kesalahan pada requirement dalam bentuk lowlevel-developer internal lainnya. Sedangkan stakeholder, user atau customer cenderung kurang peduli dengan pemodelan seperti itu. GORE menjadi salah satu cara untuk memecahkan permasalahan tersebut karen telah dilengkapi juga pada sisi high-level [3]. Goal merupakan kondisi/keadaan yang ingin dicapai oleh stakeholder. Terdapat 17 metode dalam GORE yang memiliki kelebihan dan kekurangan, dan juga termasuk metode gabungan dari metode-metode yang lain. Salah satunya adalah $\mathrm{i} *$ [2]

$i^{*}$ merupakan agent-oriented modeling framework yang dapat digunakan untuk requirement engineering, proses rekayasa ulang bisnis, analisis dampak organisasi, dan software process modeling [3]. Ketertarikan aplikasi menggunakan framework ini yaitu untuk modeling system, dan requirement. Langkahlangkah yang dilakukan dalam i* framework adalah 1) Mengidentifikasi dan memodelkan proses yang telah ada. 2) Menganalisis model yang masih terdapat kekurangan. 3) Mengusulkan proses baru yang dapat mengatasi kekurangan yang telah diitentifikasi.

Framework ini memiliki dua komponen utama, yaitu: Strategic Dependency (SD) model dan Strategic Rationale (SR) model. Strategic dependency (SD) mendeskripsikan hubungan ketergantungan antar aktor. Model ini memungkinkan untuk analisis dependensi langsung atau tidak langsung dari masingmasing aktor dan eksplorasi peluang dan kerentanan aktor [2]. Dependensi mendeskripsikan hubungan intensional antara dua aktor dengan dependum. Terdapat 4 tipe dependum yaitu, goals, tasks, resources, dan softgoals.

Strategic rational (SR) menjelaskan bagaimana aktor mencapai tujuannya. Ketika aktor terkait telah diidentifikasi, model SD dapat disimpulkan dan dapat dipindah ke dalam model SR. Sementara model SD hanya melihat hubungan antar aktor eksternal, model SR memodelkan hubungan intensional didalam suatu aktor. Model ini memungkinkan untuk pemahaman lebih dalam untuk kebutuhan tiap aktor dan bagaimana kebutuhan ini terpenuhi [3].

\subsection{Teknik Sampling}

Teknik sampling adalah merupakan teknik pengambilan sampel [4]. Teknik sampling adalah cara untuk menentukan sampel yang jumlahnya sesuai dengan ukuran sampel yang akan dijadikan sumber data sebenarnya. Untuk menentukan jumlah dari sampel, dalam penelitian ini penulis menggunakan rumus Lemeshow yaitu Cross Sectional Sample:

$$
\begin{aligned}
n & =\frac{(Z a)^{2} p(1-p)}{d^{2}} \\
& =\frac{(1,96)^{2} p(1-p)}{d^{2}}
\end{aligned}
$$


Keterangan :

$$
=\frac{4 p(1-p)}{d^{2}}
$$

$\mathrm{n}=$ Jumlah sampel/jumlah responden

$\mathrm{Za}=$ tingkat kemaknaan $/ \mathrm{Z}$ table $(1,96)$ bisa

dibulatkan menjadi 2

$\mathrm{d}^{2}=$ Presisi yang ditetapkan

$\mathrm{d}=0,1$

Dalam menentukan presisi yang ditetapkan Lemeshow adalah sebagai berikut:

Nilai $d=0,1(10 \%)$ untuk populasi dalam jumlah besar

Nilai $\mathrm{d}=0,2(20 \%)$ untuk populasi dalam jumlah kecil

Jadi rentang sampel yang dapat diambil dari rumus Lemeshow adalah antara $10-20 \%$ dari populasi penelitian.

\subsection{Skala Pengukuran}

Skala Likert merupakan metode skala bipolar yang mengukur baik tanggapan positif ataupun negatif terhadap suatu pernyataan. Skala digunakan untuk memudahkan dalam ukuran-ukuran berjenjang [5]. Skala likert terbagi dalam lima kategori yang digunakan, yaitu Sangat Tidak Setuju, Tidak Setuju, Netral, Setuju dan Sangat Setuju.

Skala Guttman adalah skala pengukuran dengan data yang diperoleh berupa data interval atau rasio dikotomi (dua alternatif). Jawaban dapat dibuat dengan skor tertinggi 1 (satu) dan terendah 0 (nol). Tipe cara pemberian bobot nilai, yaitu nilai 1 untuk jawaban "ya" dan nilai 0 untuk jawaban "tidak". Skala pengukuran dengan tipe ini, akan didapat jawaban yang tegas, yaitu "ya-tidak"; "benar-salah"; "pernahtidak pernah"; "positif-negatif"; dan lain-lain [4].

\subsection{Alur Penelitian}

Alur penelelitian yang dilakukan dapat dilihat pada gambar 2 .

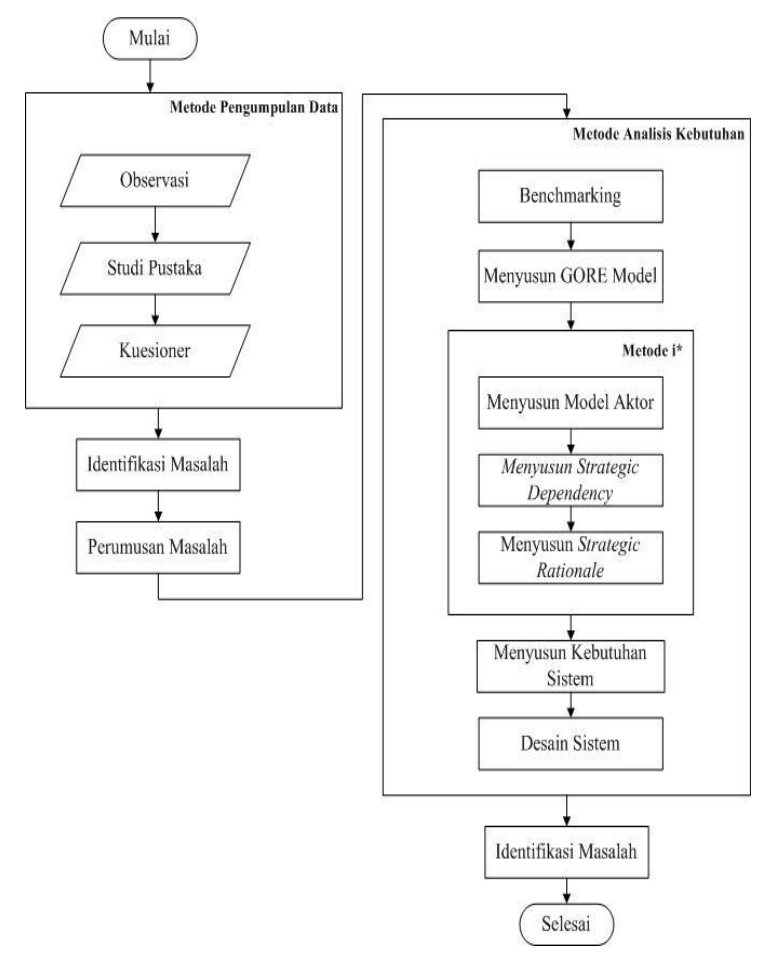

Gambar 2. Alur penelitian

\section{HASIL DAN PEMBAHASAN}

\subsection{Bechmarking}

Benchmarking dilakukan terhadap beberapa website perpustakaan UIN seperti website perpustakaan UIN Syarif Hidayatullah Jakarta, UIN Sunan Kalijaga Yogyakarta, dan UIN Maulana Malik Ibrahim. Keunggulan dari sistem yang terdapat dalam beberapa layanan wesbite tersebut digunakan sebagai acuan dalam melakukan pendefinisian kebutuhan minimum dari sistem baru guna memberikan kemudahan pengguna nantinya.

\subsection{Skala Likert dan Skala Guttman 3.2.1 Skala Likert}

Menghitung nilai usability dari website perpustakaan, langkah pertama adalah menghitung nilai berdasarkan tiap aspek penilaian yang diberikan kepada responden. Pada aspek ini terdapat dua pertanyaan yang penulis berikan kepada user. Masing-masing pertanyaan dihitung total skornya. Untuk pertanyaan pertama dapat dilihat pada Tabel 1 . 
Tabel 1. Skala, bobot nilai dan presentase penilaian kuesioner mementukan hasil analisis

\begin{tabular}{lcc}
\hline \multicolumn{1}{c}{ Skala } & $\begin{array}{c}\text { Bobot } \\
\text { Nilai }\end{array}$ & Presentase \\
\hline $\begin{array}{l}\text { Sangat Tidak } \\
\text { Setuju }\end{array}$ & 1 & $0 \%-19,99 \%$ \\
\hline Tidak Setuju & 2 & $20 \%-39,99 \%$ \\
\hline Netral & 3 & $40 \%-59,99 \%$ \\
\hline Setuju & 4 & $60 \%-79,99 \%$ \\
\hline Sangat Setuju & 5 & $80 \%-100 \%$ \\
\hline
\end{tabular}

Tabel 2. Tabel hasil jawaban pertanyaan pertama

\begin{tabular}{lc}
\hline \multicolumn{1}{c}{ Skala } & Hasil Jawaban \\
\hline Sangat Tidak Setuju & 3 \\
\hline Tidak Setuju & 20 \\
\hline Netral & 51 \\
\hline Setuju & 50 \\
\hline Sangat Setuju & 10 \\
\hline
\end{tabular}

Dari data yang didapat di atas kemudian diolah dengan cara mengkalikan setiap jawaban dengan bobot yang sudah ditentukan dengan tabel bobot nilai, dengan hasil perhitungan:

1. Responden yang menjawab Sangat Tidak Setuju (1): 3 x $1=3$

2. Responden yang menjawab Tidak Setuju (2): $20 \times 2=40$

3. Responden yang menjawab Netral (3): $51 \mathrm{x}$ $3=153$

4. Responden yang menjawab Setuju (4): $50 \mathrm{x}$ $4=200$

5. Responden yang menjawab Sangat Setuju (5): $10 \times 5=50$

Total Skor $=3+40+153+200+50=446$ Selanjutnya setelah menghitung pertanyaan pertama penulis menghitung total skor untuk pertanyaan kedua dengan menggunakan tahapan yang sama didapatkan total skor untuk pertanyaan kedua sebesar 445 .

Total Skor Fexibility and minimalist design $=\frac{446+445}{2}=445,5$

Untuk mengetahui hasil interpretasi dari presentase skala Likert, harus diketahui nilai skor tertinggi $(\mathrm{Y})$ dan terendah $(\mathrm{X})$ dengan rumus sebagai berikut:

$\mathrm{Y}=$ Skor tertinggi pada bobot nilai (5) $\mathrm{x}$ jumlah responden

$\mathrm{X}=$ Skor terendah pada bobot nilai (1) $\mathrm{x}$ jumlah responden
Jumlah nilai pada bobot nilai tertinggi (Sangat Setuju) adalah $5 \times 134=670$, sedangkan nilai pada bobot nilai terendah (Sangat Tidak Setuju) adalah 1 x $134=134$. Maka pada aspek penilaian Flexibility and minimalist design dengan total skor 445,5 dapat dihitung presentasenya dengan rumus index $\%$.

$$
\begin{gathered}
\text { Index } \%=\frac{\text { Total Skor }}{Y} \times 100 \\
\text { Index } \%=\frac{445,5}{670} \times 100 \\
\text { Index } \%=66,5 \% \text { (Setuju) }
\end{gathered}
$$

\subsubsection{Skala Guttman}

Pada skala Guttman terdapat beberapa pertanyaan yang diurutkan secara hierarki untuk melihat sikap tertentu dari sederetan pernyataan termuda ke pertanyaan tersulit. Hasil dari data yang diperoleh tersebut dipindahkan ke tabel distribusi frekuensi yang masih dalam tahap perhitungan skala Guttman.

Tabel 1. Tabel hasil distribusi frekuensi skala guttman

\begin{tabular}{ccc}
\multicolumn{3}{c}{ guttman } \\
Pertanyaan & $\begin{array}{c}(\%) \\
\text { Jawaban Ya }\end{array}$ & $\begin{array}{c}(\%) \\
\text { Jawaban } \\
\text { Tidak }\end{array}$ \\
\hline P11 & 99 & 35 \\
\hline P12 & 105 & 29 \\
\hline P17 & 108 & 23 \\
\hline P15 & 111 & 23 \\
\hline P18 & 80 & 54 \\
\hline P14 & 81 & 53 \\
\hline P16 & 45 & 89 \\
\hline P10 & 106 & 28 \\
\hline P20 & 82 & 52 \\
\hline Total & 817 & 386 \\
\hline Rata-rata & 90,8 & 42,8 \\
\hline
\end{tabular}

Dari penghitungan Tabel 3 dapat dihitung nilai usability dari skala Guttman dengan rata-rata nilai dari tiap aspek yang menjawab Ya dan dibagi dengan jumlah responden yang didapat dengan mengkalikan hasil maksimal pertanyaan, jawaban Tidak bernilai 0 maka tidak perlu dihitung. Maka didapatkan nilai Usability dengan menggunakan rumus index\%.

Presentase usability website

$=\frac{\text { Rata }- \text { rata }}{\text { Jumlah responden }} \times 100 \%$
$=\frac{90,8}{134} \times 100 \%$ 
$=67,7 \%($ Setuju $)$

\subsection{Diagram SD dan SR}

Perancangan desain dilakukan berdasarkan GORE menggunakan i* framework yang dimodelkan menggunakan strategic dependency diagram, dan strategic rationale diagram. Diagram-diagram tersebut dipilih karena dipandang lebih sesuai untuk memodelkan alur proses dari goal yang dihasilkan dari proses GORE dan merupakan diagram dalam $\mathrm{i}^{*}$ framework. Untuk selanjutnya model-model tersebut dapat mengarahkan desain dan evaluasi sistem yang diusulkan, berikut penjelasannya:

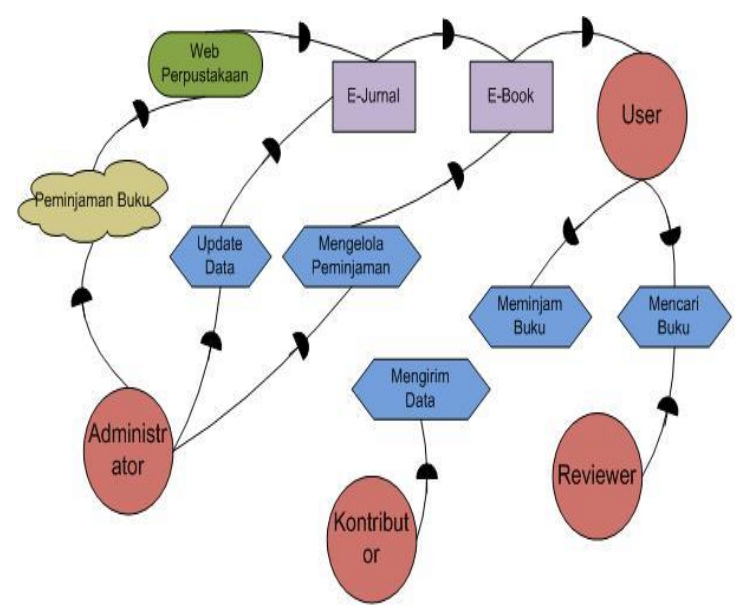

Gambar 3. Diagram strategic dependency

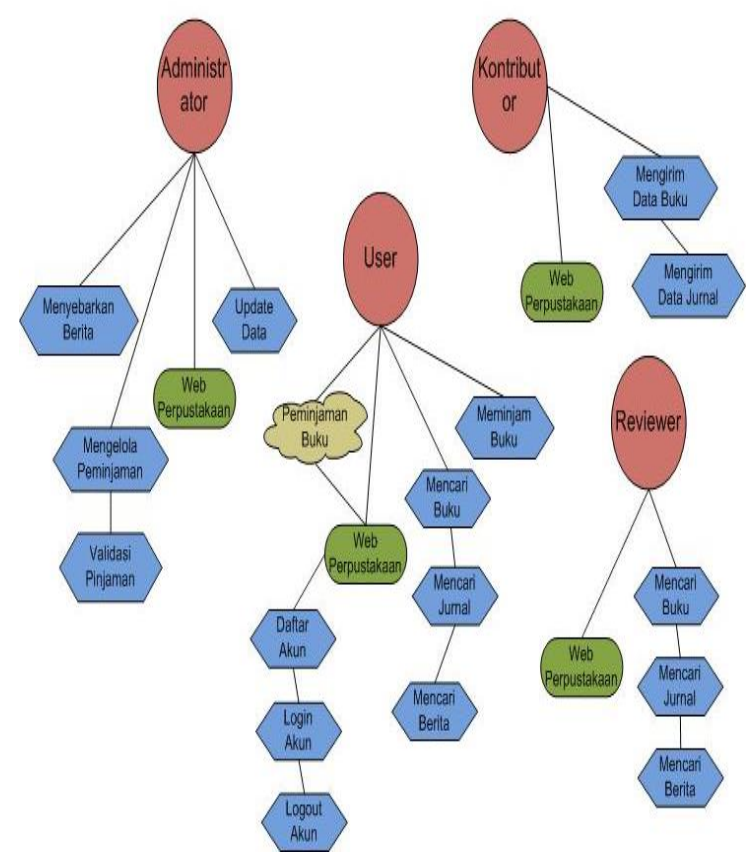

Gambar 4. Diagram strategic rationale

\subsection{Daftar Kebutuhan Sistem}

Daftar kebutuhan sistem dapat dilihat pada Tabel 4 berikut ini.

Tabel 4. Hasil kebutuhan fungsional

\begin{tabular}{cl}
\hline ID & \multicolumn{2}{c}{ Kebutuhan Fungsional } \\
\hline KF01 & $\begin{array}{l}\text { Sistem dapat menampilkan } \\
\text { buku/jurnal yang tersedia. }\end{array}$ \\
\hline KF02 & $\begin{array}{l}\text { Sistem menyediakan fitur } \\
\text { peminjaman buku secara online. }\end{array}$ \\
\hline KF03 & $\begin{array}{l}\text { Tampilan sistem dalam bentuk } \\
\text { mobile. }\end{array}$ \\
\hline KF04 & $\begin{array}{l}\text { Sistem menyediakan fitur lihat } \\
\text { buku/jurnal. }\end{array}$ \\
\hline KF05 & $\begin{array}{l}\text { Sistem menyediakan fitur unduh } \\
\text { jurnal. }\end{array}$ \\
\hline KF06 & $\begin{array}{l}\text { Sistem meyediakan fitur pencarian } \\
\text { buku/jurnal. }\end{array}$ \\
\hline KF07 & $\begin{array}{l}\text { Terdapat fitur chat room dalam } \\
\text { sistem m }\end{array}$ \\
\hline KF08 & $\begin{array}{l}\text { Sistem menampilkan gambar buku } \\
\text { yang tersedia. }\end{array}$ \\
\hline KF09 & $\begin{array}{l}\text { Sistem menyediakan fitur registrasi } \\
\text { anggota }\end{array}$ \\
\hline KF10 & Sistem menyediakan fitur login. \\
\hline
\end{tabular}

Tabel 5. Hasil kebutuhan non fungsional

\begin{tabular}{ll}
\hline ID & Kebutuhan non Fungsional \\
\hline KnF01 & $\begin{array}{l}\text { Sistem dapat menampilkan } \\
\text { hasil pencarian buku/jurnal } \\
\text { dalam waktu kurang dari 5 } \\
\text { detik. }\end{array}$ \\
\hline KnF02 & $\begin{array}{l}\text { Sistem mampu menyimpan } \\
\text { data yang dikirimkan } \\
\text { kontributor dalam jumlah } \\
\text { banyak. }\end{array}$ \\
& $\begin{array}{l}\text { User dapat men-download } \\
\text { tata tertib perpustakaan yang } \\
\text { terdapat pada sistem }\end{array}$ \\
\hline KnF03 & $\begin{array}{l}\text { Daftar buku yang tersedia } \\
\text { dalam katalog maksimal 1000 } \\
\text { buku. }\end{array}$ \\
\hline KnF05 & $\begin{array}{l}\text { Terdapat menu pencarian } \\
\text { yang digolongkan } \\
\text { berdasarkan Penerbit, Tahun } \\
\text { Terbit, Pengarang, Jenis } \\
\text { Buku. }\end{array}$ \\
\hline KnF06 & $\begin{array}{l}\text { Sistem harus mudah } \\
\text { digunakan oleh pengguna. }\end{array}$ \\
\hline
\end{tabular}




\subsection{Hasil Tampilan Antarmuka}

Dari hasil analisis pada subbab sebelumnya, maka dapat digambarkan rancangan dari antarmuka website perpustakaan yang baru. Gambar 5 berikut merupakan tampilan antarmuka pada sistem ini.
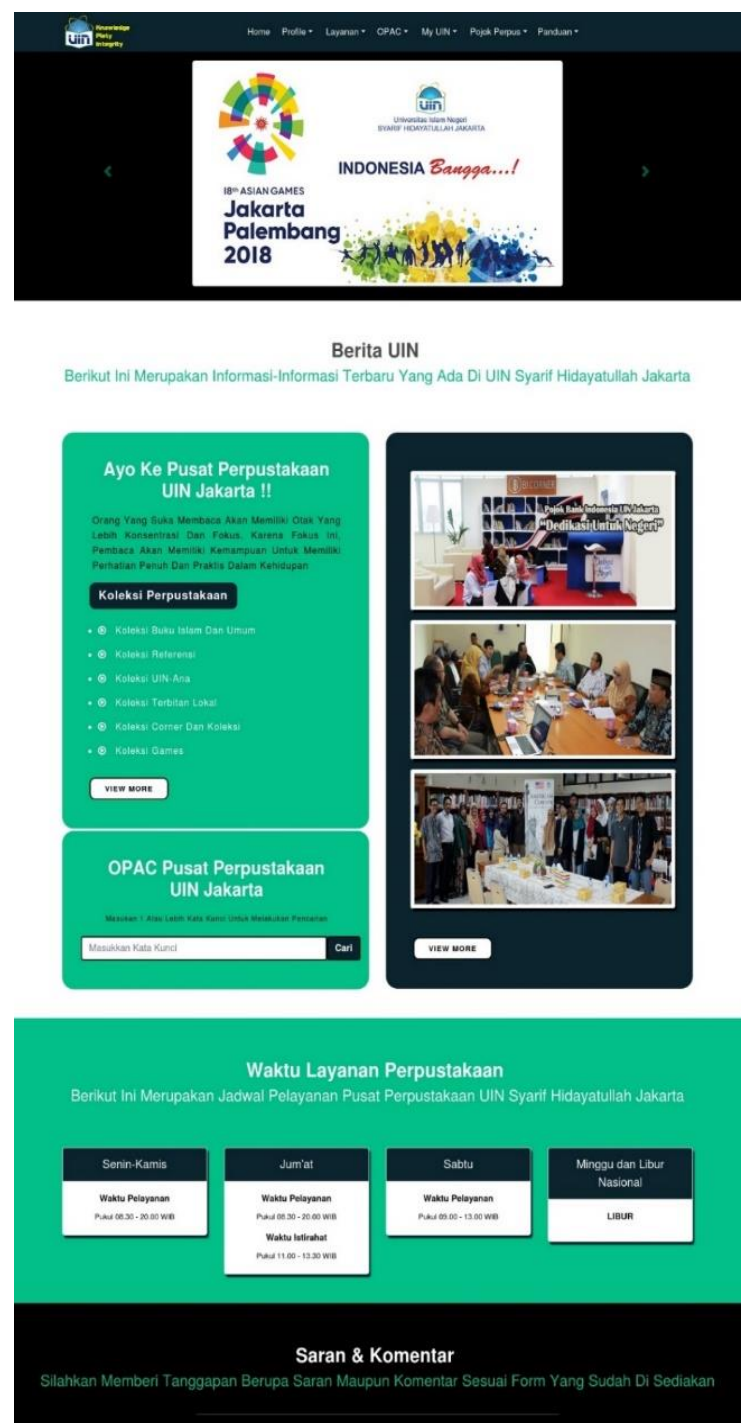

Gambar 5. Halaman antar muka

Tabel 6 berikut merupakan simpulan dari hasil dari requirement ketiga website perpustakaan yang telah terealisasikan saat ini.

Tabel 2. Hasil benchmarking dan requirement

\begin{tabular}{cccccc}
\multicolumn{5}{c}{ website } \\
\hline \multirow{3}{*}{ Requirement } & UIN & UIN & UIN & Sistem & KF/ \\
& JKT & YGA & MLG & Baru & KnF
\end{tabular}

\begin{tabular}{llllll}
\hline Sistem & & & & & \\
menampilkan & - & - & - & $\checkmark$ & $\mathrm{KF}$ \\
buku/jurnal & & & & & \\
yang tersedia. & & & & & \\
\hline
\end{tabular}

\begin{tabular}{|c|c|c|c|c|c|}
\hline $\begin{array}{l}\text { Sistem } \\
\text { menyediakan } \\
\text { fitur } \\
\text { peminjaman } \\
\text { buku secara } \\
\text { online. }\end{array}$ & - & $\checkmark$ & - & $\checkmark$ & $\mathrm{KF}$ \\
\hline $\begin{array}{l}\text { Tampilan sistem } \\
\text { dalam bentuk } \\
\text { mobile. }\end{array}$ & $\checkmark$ & $\checkmark$ & $\checkmark$ & $\checkmark$ & $\mathrm{KF}$ \\
\hline $\begin{array}{l}\text { Sistem mampu } \\
\text { menyimpan data } \\
\text { yang dikirimkan } \\
\text { kontributor } \\
\text { dalam jumlah } \\
\text { banyak. }\end{array}$ & - & - & - & - & $\mathrm{KnF}$ \\
\hline $\begin{array}{l}\text { User dapat } \\
\text { mengunduh tata } \\
\text { tertib } \\
\text { perpustakaan }\end{array}$ & - & - & - & - & $\mathrm{KnF}$ \\
\hline $\begin{array}{lr}\text { Daftar } & \text { buku } \\
\text { yang } & \text { tersedia } \\
\text { dalam } & \text { katalog } \\
\text { maksimal } & 1000 \\
\text { buku. } & \\
\end{array}$ & - & - & - & - & $\mathrm{KnF}$ \\
\hline $\begin{array}{l}\text { Fitur pencarian } \\
\text { buku/jurnal. }\end{array}$ & $\checkmark$ & $\checkmark$ & $\checkmark$ & $\checkmark$ & $\mathrm{KF}$ \\
\hline $\begin{array}{l}\text { Sistem harus } \\
\text { mudah } \\
\text { digunakan oleh } \\
\text { pengguna. }\end{array}$ & - & - & - & - & $\mathrm{KnF}$ \\
\hline $\begin{array}{l}\text { Sistem dapat } \\
\text { menampilkan } \\
\text { hasil pencarian } \\
\text { buku/jurnal } \\
\text { dalam waktu } \\
\text { kurang dari } 5 \\
\text { detik. }\end{array}$ & - & - & - & - & $\mathrm{KnF}$ \\
\hline $\begin{array}{l}\text { Sistem } \\
\text { menyediakan } \\
\text { fitur lihat } \\
\text { buku/jurnal. }\end{array}$ & $\checkmark$ & - & - & $\checkmark$ & $\mathrm{KF}$ \\
\hline $\begin{array}{l}\text { Sistem } \\
\text { menyediakan } \\
\text { fitur unduh } \\
\text { jurnal. }\end{array}$ & - & - & - & $\checkmark$ & $\mathrm{KF}$ \\
\hline $\begin{array}{l}\text { Ada menu } \\
\text { pencarian yang } \\
\text { digolongkan } \\
\text { berdasarkan } \\
\text { Penerbit, Tahun } \\
\text { Terbit, } \\
\text { Pengarang, } \\
\text { Jenis Buku }\end{array}$ & - & - & - & - & $\mathrm{KnF}$ \\
\hline $\begin{array}{l}\text { Ada fitur chat } \\
\text { room di sistem }\end{array}$ & - & - & - & $\checkmark$ & $\mathrm{KF}$ \\
\hline $\begin{array}{l}\text { Sistem } \\
\text { menampilkan } \\
\text { gambar buku } \\
\text { yang tersedia. }\end{array}$ & - & - & - & $\checkmark$ & $\mathrm{KF}$ \\
\hline
\end{tabular}




\begin{tabular}{|c|c|c|c|c|c|}
\hline $\begin{array}{l}\text { Sistem } \\
\text { menyediakan } \\
\text { fitur registrasi } \\
\text { anggota }\end{array}$ & - & - & - & $\checkmark$ & $\mathrm{KF}$ \\
\hline $\begin{array}{l}\text { Sistem } \\
\text { menyediakan } \\
\text { fitur login. }\end{array}$ & - & $\checkmark$ & - & $\checkmark$ & $\mathrm{KF}$ \\
\hline
\end{tabular}

\section{KESIMPULAN}

Analisis dimulai dengan identifikasi masalah, mengumpulkan data melalui studi pustaka dan kuesioner, kemudian dilakukan perbandingan. Kesimpulan yang dapat diambil adalah sebagai berikut:

1. Ketiga website perpustakaan UIN Jakarta, UIN Yogyakarta dan UIN Malang sudah memenuhi kebutuhan user tetapi usabilitynya belum maksimal. Requirement yang telah dihasilkan adalah perlunya fitur peminjaman buku, update data buku dan jurnal, task mencari buku, task mengelolah pinjaman buku, mengirim data buku dan jurnal. Hasil analisis website perpustakaan menggunakan metode bechmarking dilakukan dengan menggunakan metode kuesioner dengan perhitungan menggunakan skala Likert dan skala Guttman. Kedua skala tersebut menghasilkan usablity sebanyak $67 \%$ setuju dengan website yang ada saat ini dengan syarat perlunya perbaikan kembali.

2. Elemen-elemen pada setiap aktor diagram Strategic Rationale saling bergantung dan berkaitan untuk mencapai tujuan website perpustakaan, dan hubungan dependensinya telah sesuai dengan dependensi pada diagram Strategic Depenedency. Goal yang sebenarnya ingin dicapai dalam penelitian ialah peningkatan usability dan perbaikan desain antarmuka.

3. Website perpustakaan UIN Syarif Hidayatullah Jakarta yang telah dirancang dan dianalisis belum sepenuhnya memenuhi kebutuhan dari user dikarenakan masih ada kekurangan pada website, penulis belum menilai website pada aspek penilaian yang lain dari Benchmarking dan metode GORE yang lain. Website hanya dibandingkan dengan website perpustakaan sesama UIN dengan semua kebutuhan yang diperoleh dari kuesioner serta pembuatan prototipe.

\section{DAFTAR PUSTAKA}

[1] F. Adikara. dan A. Pambudi, "Analisis Kebutuhan Stakeholder Dalam Rangka Mengembangkan Model Tata Kelola Teknologi Informasi dengan Kerangka Kerja COBIT-5 Pada Perguruan Tinggi", Prosiding KNTI, 2012.

[2] I. M. Shofi dan E. K. Budiardjo, "Klasifikasi Metode GORE Dan Kemungkinannya Untuk Mengembangkan Aplikasi Kepemerintahan", Semantik, 2011.

[3] A. Lapouchnian, Goal Oriented Requirements Engineering An Overview of the Current Research. Department of Computer Science Of Toronto, 2005.

[4] Sugiyono, Metode Penelitian Kuantitatif, Kualitatif. Bandung: CV. Alfabeta, 2015.

[5] H. N. J. Boone and D. A. Boone, "Analyzing Likert data," J. Ext., vol. 50, no. 2, 2012, pp. 30. 